\title{
Zika virus infection and autonomic symptoms
}

\author{
Beuy Joob ${ }^{1} \cdot$ Viroj Wiwanitkit ${ }^{2,3}$
}

Received: 3 March 2018 / Accepted: 6 March 2018 / Published online: 12 March 2018

(c) Springer-Verlag GmbH Germany, part of Springer Nature 2018

\section{Dear Editors,}

We read with interest the article by Rodriguez and colleagues regarding autonomic symptoms following Zika virus infection. The authors concluded that "Zika virus infection is associated with autonomic dysfunction. The mechanisms remain to be elucidated [1]". In fact, neurological problems are a well-known complication of Zika virus infection, but autonomic dysfunction is seldom reported. We would like to share our experience in Thailand, where Zika virus infection is also prevalent. The infection is usually asymptomatic [2] and neurological deficits, including autonomic dysfunction, are rarely observed. Regarding the pathogenesis, the potential explanation for autonomic dysfunction in these patients might be linked to the immune changes seen in the Zika virus-related Guillain-Barré syndrome [3]. According to the editorial comment by Carod-Artal, further research in this area is suggested [4].

\section{Beuy Joob}

beuyjoob@hotmail.com

Sanitation 1 Medical Academic Center, Bangkok, Thailand

2 Hainan Medical University, Haikou, China

3 Dr DY Patil University, Pune, India

\section{Compliance with ethical standards}

Conflict of interest The authors declare that they have no competing interests.

\section{References}

1. Rodríguez Y, Rojas M, Ramírez-Santana C, Acosta-Ampudia Y, Monsalve DM, Anaya JM (2018) Autonomic symptoms following Zika virus infection. Clin Auton Res. https://doi.org/10.1007/ s10286-018-0515-1 [Epub ahead of print]

2. Wiwanitkit S, Wiwanitkit V (2016) Afebrile, asymptomatic and non-thrombocytopenic Zika virus infection: don't miss it! Asian Pac. J Trop Med 9(5):513

3. Rodríguez Y, Rojas M, Pacheco Y, Acosta-Ampudia Y, RamírezSantana C, Monsalve DM, Gershwin ME, Anaya JM (2018) Guillain-Barré syndrome, transverse myelitis and infectious diseases. Cell Mol Immunol. https://doi.org/10.1038/cmi.2017.142 [Epub ahead of print]

4. Carod-Artal FJ (2018) Autonomic dysfunction: a novel neurological phenotype associated with Zika virus infection? Clin Auton Res. https://doi.org/10.1007/s10286-018-0516-0 [Epub ahead of print] 